

Kantor Editor : Lantai 2 Fakultas Syariah IAIN Purwokerto

J1. A. Yani No. 40A Purwokerto Jawa Tegah 53126 Indonesia

Telp. : : +62 281635624 Fax. +62 281636653

E-Mail : volksgeist@iainpurwokerto.ac.id

ISSN Online 2615-174X

Website : http://ejournal.iainpurokerto.ac.id/index.php/volksgeist

\title{
Zakat Atas Hak Kekayaan Intelektual Perspektif Teori an-Nama' Yusuf Qaradhawi
}

\author{
Imam Agung Prakoso \\ Institut Agama Islam Negeri Pontianak \\ Email : imamagungprakz@gmail.com
}

\begin{abstract}
Abstrak
Tujuan artikel ini untuk mengetahui Hak Atas Kekayaan Intelektual menurut teori an-Nama' Yusuf Qardhawi dan bagaimana perhitungan zakatnya. Teori yang mendasari dalam penelitian ini yaitu teori zakat an-Nama', zakat profesi, dan hak atas kekayaan intelektual sebagai harta, dan harta tak berwujud. Jenis penelitian menggunakan penelitian isi dengan pendakatan Normatif Yuridis, Metode penelitian menggunakan tinjauan pustaka, sumber data mengambil data primer dan sekunder, teknis analisis data menggunakan model Interaktif. Hasil penelitian menunjukkan bahwa Zakat Hak atas kekayaan intelektual yang didasarkan pada teori An-Nama' Yusuf Qardhawi merupakan bagian zakat Profesi, karena HAKI memiliki nilai ekonomi, yang dihasilkan dari kreatifitas Intelektual yang diwujudkan dengan karya-karyanya, sehingga HAKI merupakan kekayaan yang tak berwujud yang dapat berkembang. Kemudian perhitungan zakat HAKI yakni sebesar $2.5 \%$ dari penghasilan yang didapat setelah dikeluarkan kewajiban pokok.
\end{abstract}

Kata Kunci: Zakat, an-Nama', Hak Kekayaan Intelektual

\begin{abstract}
This article aims to find out the Intellectual Property Rights according to an-Nama' Yusuf Qardhawi theory Qardhawi' and how the zakat is calculated. The underlying theories used in this study are zakat theory an-Nama', zakat profession, intellectual property right as a form of wealth, and intangible property. This study is a content analysis using normative legal approach. The research method used in this study is library research by collecting the data from primary and secondary data. The data is analyzed using interactive model. The findings showed that zakat on Intellectual Property Rights based on an-Nama' theory by Yusuf Qaradhawi is a part of zakat on profession because IPRs have economic value, obtained from intellectual creativity manifested in the forms of works. Therefore, IPRs are a form of intangible property that could develop. In addition, the calculation of zakat on IPR is $2.5 \%$ of the income earned after deducted by tax obligations.
\end{abstract}

Keywords: Zakat, An-Nama', Intellectual Property Rights

\section{Sejarah Artikel}

Diterima: 04 Februari 2020;

Direview: 28 April 2020;
Diterima: 16 Mei 2020;

Diterbitkan: 18 Juni 2020;

Sitasi: V.3.1 volksgeist 2020; 


\section{Pendahuluan}

Seiring perkembangan zaman dan teknologi kebutuhan tentu berimplikasi bagi kehidupan manusia secara umum dan juga berpengaruh dalam kehidupan beragama. Salah satu wujud perkembangan teknologi di era globlasisasi ini adalah hadirnya jenis kepemilikan harta baru yang kemudian disebut dengan istilah Hak Kekayaan Intelektual (HKI). HKI pada hakikatnya merupakan sebuah hak yang berasal dari karya, karsa dan daya cipta manusia yang berupa hasil intelektulitas manusia. Sebagai sebuah hasil karya cipta manusia, HKI tentu memiliki manfaat dan bernilai ekonomi.

Sebagai sebuah penemuan terhadap karya cipta manusia maka wajar jika penemu atas inovasi dan kreasi tersebut mendapat keuntungan secara ekonomi. Tidak berhenti disitu, bahwa sebagai konsekuensi dari sebuah penemuan yang memiliki nilai kemanfaatan ekonomi, maka penemuan terhadap hasil inovasi dan kreasi tersebut harus mendapat perlindungan. Adanya perlindungan dan rasa aman dapat membangkitkan semangat dan minat dalam melahirkan karya cipta baru.

Pada perkembangannya, HKI dihadapkan berbagai persoalan. Pertama, HKI termasuk dalam masalah baru yang baru dikenal oleh masyarakat modern. Kedua, sebagian masyarakat Muslim beranggapan bahwa konsep HKI merupakan produk Barat yang bernuansa kapitalis, bahkan berbeda dengan Islam karena dianggap sebagai bentuk monopoli terhadap ilmu pengetahuan. Ketiga, terdapat teks keagamaan yang menyebut bahwa ilmu pengetahuan merupakan salah satu amal jariyah yang dapat mendatangkan pahala secara terus menerus. ${ }^{1}$

Para ulama berbeda pendapat terkait keberadaan HKI sebagai salah satu hasil karya cipta manusia yang memiliki nilai ekonomi. Dalam pandangan fiqh, ada yang berpendapat bahwa HKI termasuk dalam kategori hak immaterial (al-huqūq alma'nawiyah). Terdapat dua hal yang menjadi sorotan, pertama, karya intelektual yang sebelum berwujud buku atau benda setara lainnya masih berupa deskripsi tentang pemikiran yang bersifat abstrak. Kedua, karya intelektual harus memenuhi unsur penciptaan atau penemuan $\left(a l-i b d a^{\prime}\right)$. Namun demikian, diskursus ini terus berkembang sampai pada persoalan hubungan pemilik atau penemu terhadap hasil temuan atau karya. Ada yang mengatakan bahwa hubungan antara keduanya telah terpisah sebagai perumpamaan manfaat buah-buahan yang sudah dipetik atau jatuh dari pohonnya. Namun lainnya berpendapat bahwa hal tersebut berbeda dengan hubungan karya dengan penemu atau penulisnya.

HKI sebagai fenomena atas perkembangan globalisasi ekonomi saat ini menarik untuk dikaji dan dielaborasi lebih mendalam. Islam sebagai agama yang menjunjung tinggi hak-hak kemanusiaan berprinsip untuk mengorientasikan kemashlahatan sebesar-besarnya termasuk merespon perkembangan konsep hak milik. Oleh karena itu, Islam menghargai ilmu pengetahuan dan mendorong adanya produktivitas karya inovasi manusia.

Sebagai sebuah unsur yang bermanfaat dan bernilai ekonomi, maka diskusi selanjutnya adalah HKI juga

${ }^{1}$ Asmuni Mth, "Hak Milik Intelektual dalam Perspektif Fiqh Islam," Jurnal al-Mawarid Edisi IX (2003): 29. 
merupakan bagian yang harus dizakati. Zakat merupakan salah satu perintah dalam Islam, dimana dalam Al-Quran disebutkannya zakat setelah disebutkannya sholat ini menunjukkan betapa pentingnya masalah zakat karena ia merupakan tanda keimanan seseorang dan modal keselamatannya. ${ }^{2}$ Selain itu juga, untuk mengatur kesejahteraan dan keseimbangan dalam kesejahteraan sosial, agama Islam juga telah mengaturnya secara khusus di dalam hal zakat. Zakat merupakan hal sangat penting dalam Islam, karena dalam ajaran agama Islam, Islam sangat memperhatikan kemaslahatan tiap umatnya. Sehingga, untuk menumbuhkan rasa kepedulian antar sesama, maka agama Islam mewajibkan bagi umatnya yang mempunyai kelebihan hartanya untuk diberikan pada golongan yang membutuhkan.

Zakat mempunyai kekhususan, yaitu dari umat Islam oleh umat Islam dan untuk umat Islam dengan sasaran khusus, seperti tersebut dalam al-Qur'an surah at-Taubah (9) ayat 60 , bahwa yang berhak menerima harta zakat (mustahik) adalah: fakir, miskin, amil, mu'allaf, ghorimin, riq $\bar{\alpha} b$, sabîlillāh, dan ibnu sabîl. ${ }^{3}$

Zakat memiliki peran penting dalam menggerakkan ekonomi. Karena seorang Muslim yang menyimpan harta, memiliki kewajiban nuntuk mengeluarkan zakatnya minimal 2,5\% setiap tahunnya. Sehingga ini dapat memperkecil kesenjangan sosial yang terjadi di masyarakat. Islam mengakui adanya perbedaan rezeki, ini diakibatkan adanya perbedaann kemampuan, keahlian,

${ }^{2}$ M. Husein Falah Zadeh, Belajar Fiqih untuk Tingkat Pemula (Jakarta: Raja Grafindo Persada, 2008), 223.

${ }^{3}$ Teungku Muhammad Hasbi ash-Shiddieqy, Pedoman Zakat, Cet. 2 (Semarang: Pustaka Rizki Putra, 1999), 19. dan potensi pada tiap individu. Pada saat yang bersamaan Islam menolak keadaan sosial ekonomi yang timpang, dimana pada satu sisi hidup penuh dengan kenikmatan dan pada sisi yang lain hidup penuh dengan kemelaratan atau kemiskinan. Pada poin ini Islam menginginkan atau menghendaki orang-orang miskin untuk dapat menikmati kesenangan orang kaya dan memberinya apa yang dapat dapat mencukupi atau mengcover hajatnya. Dan zakat menjadi satu dari banyak sarana yang dipergunakan Islam untuk mencapai tujuan tersebut. ${ }^{4}$

Islam telah mengatur beberapa hal yang wajib dikeluarkan zakatnya sejak zaman awal datangnya Islam. Namun seiring berkembangnya zaman, maka banyak pula sumber penghasilan yang baru di era modern ini, sehingga perlu adanya kajian yang lebih mendalam tentang pengaturan atau pembagian zakat itu sendiri. Salah satunya adalah harta atau kekayaan yang bersumber dari kekayaan intelektual yang dimiliki oleh tiap orang.

Hal ini menjadi sangat penting untuk dibahas, mengingat perkembangan zaman yang sangat pesat serta memunculkan ide-ide baru yang dapat menjadi sumber penghasilan di era-modern seperti saat ini. Dimana muncul hak-hak paten, hak cipta, dan hakhak yang lain yang dapat menambah penghasilan atau menjadi sumber penghasilan. Karena pada dasarnya hukum memperlakukan hak atas kekayaan intelektual (intellectual property) ini sebagai bagian dari kekayaan yang tidak berwujud. Yang pada dasarnya hak tersebut merupakan hak

\footnotetext{
${ }^{4}$ Nurul Huda dkk., Zakat Perspektif MikroMakro: Pendekatan Riset, Cet. 1 (Jakarta: Prenadamedia Group, 2015), 9.
} 


\section{Volksgeist}

Vol. 3 No. 1 Juni 2020

DOI 10.24090/volksgeist.v3i1.3503

kebendaan dalam bidang hukum kekayaan, hak tersebut memiliki nilai uang tertentu. ${ }^{5}$

Beberapa penelitian yang mengkaji mengenai zakat dan hak atas kekayaan intelektual: 1) "Zakat Profesi dalam Pandangan Islam" karya Deny Setiawan."; 2) Dimas Fahmi Fikri dan Afif Noor, dengan judul "Reformasi Hukum Wakaf Di Indonesia Studi Terhadap Wakaf Hak Atas Kekayaan Intelektual."; 3) Aristoni dan Junaidi Abdullah dalam jurnal "Reformasi Harta Sebagai Sumber Zakat Dalam Perspektif Ulama Kontemporer". Berdasarkan telaah tersebut diatas penulis belum menemukan pokok bahasan yang sama dengan yang penulis ajukan dalam karya ini, dimana penulis memfokuskan bahasannya yakni tentang zakat Hak Kekayaan Intelektual dalam tinjauan teori zakat $A n$ Nama' Yusuf Qardhawi.

\section{Pembahasan}

\section{Tinjaun Umum Zakat Profesi}

Abdul Hasan al Wahidi mengatakan bahwa zakat mensucikan harta dan memperbaikinya, serta menyuburkannya. Menurut pendapat yang lebih nyata, zakat itu bermakna kesuburan dan penambahan serta perbaikan. Asal maknanya, penambahan kebajikan. $^{6}$

Sedangkan menurut Hasbullah Bakry, ia menyatakan bahwa zakat yang berasal dari awal kata zakka, tuzakki, zakat memiliki arti bahwa zakat itu membersihkan atau mensucikan setiap orang yang memiliki harta lebih dari yang bukan haknya. ${ }^{7}$ Hal ini

\footnotetext{
${ }^{5}$ Tim Penulis Pusat HKI FH UII, Wakaf Hak Kekayaan Intelektual (Yogyakarta: Fakultas Hukum UII, 2016), 7.

${ }^{6}$ Asnaini, Zakat Produktif dalam Perspektif Hukum Islam, Cet. 1 (Yogyakarta: Pustaka Pelajar, 2008), 23.

${ }^{7}$ Hasbullah Bakry, Pedoman Islam di Indonesia, cet. 5 (Jakarta: UI Press, 1988), 243.
}

sesuai dengan firman Allah Swt dalam AlQur'an surat At-Taubah ayat [103]:



"Ambilah zakat dari sebagian harta mereka, dengan zakat itu kamu membersihkan dan mensucikan mereka, dan berdoalah untuk mereka. Sesungguhnya doa mu itu (menumbuhkan) ketentraman jiwa bagi mereka. Dan Allah Maha Mendengar Lagi Maha Mengetahui."

Makna zakat dalam syariah terkandung dua aspek didalamnya. Pertama, sebab dikeluarkannya zakat itu karena adanya proses tumbuh kembang pada aspek pahala yang semakin banyak dan subur disebabkan mengeluarkan zakat. Atau keterkaitan adanya zakat itu semata-mata karena memiliki sifat tumbuh kembang seperti zakat tijōrah dan zirō'ah. Kedua, pensucian karena zakat adalah pensucian atas kerakusan, kebakhilan jiwa, dan kotoran-kotoran lainnya, sekaligus pensucian jiwa manusia dari dosa-dosanya. ${ }^{8}$

Zakat menurut istilah fikih berarti sejumlah harta tertentu yang diwajibkan Allah diserahkan kepada orang-orang yang berhak. Nawawi juga mengutip pendapat Wahidi bahwa jumlah yang dikeluarkan dari kekayaan itu disebut zakat karena yang dikeluarkan itu menambah banyak, membuat lebih berarti dan melindungi kekayaan itu dari kebinasan. ${ }^{9}$

\footnotetext{
${ }^{8}$ Wawan Shofwan Shalehuddin, Risalah Zakat: Infak dan Shadaqah, Cet. 1 (Bandung: Tafakur, 2011), 12-13.

${ }^{9}$ Yusuf Qardawi, Hukum Zakat, trans. oleh Salman Harun, Didin Hafidhuddin, dan
} 
Menurut undang-undang Nomor 23 Tahun 2013 tentang Pengelolaan Zakat, zakat adalah harta yang wajib dikeluarkan oleh seorang muslim atau badan usaha untuk diberikan kepada yang berhak menerimanya sesuai syariat Islam. ${ }^{10}$ Zakat merupakan kewajiban bagi setiap umat Islam, selain itu zakat merupakan salah satu dari rukun Islam. Perintah mengeluarkan zakat terdapat dalam al-Qur'an dan hasits secara sejelas (Sharih). Yakni diantaranya sebagai berikut:

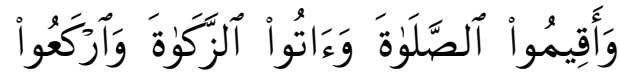



"Dan dirikanlah shalat, tunaikanlah zakat dan ruku'lah beserta orang-orang yang ruku'.’(Qs. Al-Baqarah: 43)

Islam menegaskan hukum zakat tidak hanya dengan perintah-perintah seperti yang tersebut dalam beberapa ayat diatas, akan tetapi dalam Islam juga ada ancamanancaman bagi yang tidak menunaikan atau menjalankan zakat sedangkan mereka mampu atau berkecukupan. ${ }^{11}$ Ini dapat terlihat dalam firman Allah SWT sebagai berikut:

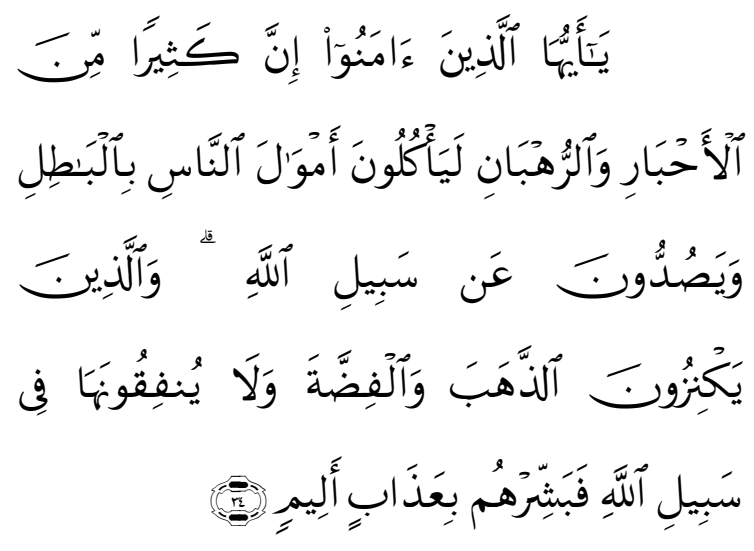

Hasanuddin, Cet. 10 (Jakarta: Pustaka Litera AntarNusantara, 2007), 34-35.

${ }^{10}$ Pemerintah Republik Indonesia, UndangUndang Nomor 23 Tahun 2013 tentang Pengelolaan Zakat, 2013.

${ }^{11}$ Asnaini, Zakat Produktif, 31.
"Hai orang-orang yang beriman, sesungguhnya sebahagian besar dari orang-orang alim Yahudi dan rahibrahib Nasrani benar-benar memakan harta orang dengan jalan batil dan mereka menghalang-halangi (manusia) dari jalan Allah. Dan orangorang yang menyimpan emas dan perak dan tidak menafkahkannya pada jalan Allah, maka beritahukanlah kepada mereka, (bahwa mereka akan mendapat) siksa yang pedih.”(Qs. At. Taubah: 34)

Yusuf al-Qaradhawi membagi pekerjaan yang menghasilkan uang menjadi dua macam. Pertama bahwa pekerjaan yang didasari dengan kemampuan diri sendiri atau dikerjakan sendiri tanpa tergantung kepada orang lain, berkat kecekatan tangan maupun otak. Kedua adalah pekerjaan yang dikerjakan seseorang buat pihak lain, baik pemerintah, perusahaan maupun perorangan dengan memperoleh upah yang diberikan berdsarakan pekerjaaan yang dilakukan dengan anggota tubuhnya atau otaknya (akal), atau keduanya. Penghasilan dari pekerjaan itu seperti berupa gaji, upah, ataupun honorarium. $^{12}$

Yusuf al-Qaradhawi mengatakan bahwa harta kekayaan yang diperoleh dari sumber mata pencahaarain yang legal (sah) yang telah mencapai nisabnya wajib dikeluarkan zakat. Termasuk didalamnya kekayaan yang dihasilkan dari penghasilan profesi. Hasil pemikirannya didasarkan pada al-Qur'an, sunnah dan logika. ${ }^{13}$

Adapun ayat Al-Qur'an yang digunakan oleh Yusuf Al-Qaradhawi dalam

\footnotetext{
${ }^{12}$ Qardawi, Hukum Zakat, 459.

${ }^{13}$ Abdul Aziz Dahlan dkk., Ensiklopedia Hukum Islam, ed. oleh Abdul Aziz Dahlan (Jakarta: PT. Ikhtiar Baru Van Hoeve, 1997), 1449.
} 
mengambil hukum zakat profesi adalah surat Al-Baqarah ayat 267.
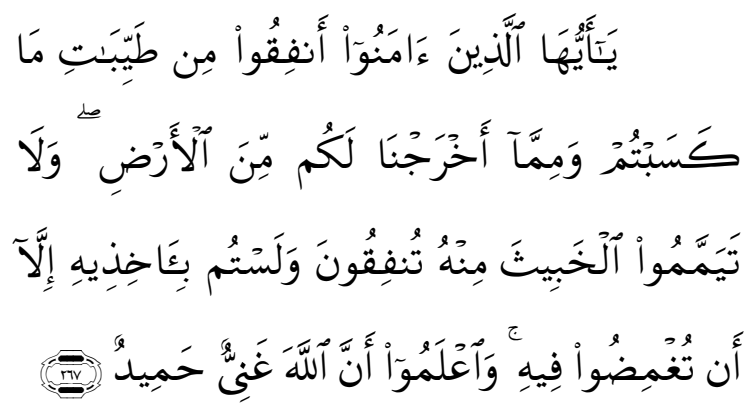

"Hai orang-orang yang beriman, nafkahkanlah (di jalan allah) sebagian dari hasil usahamu yang baik-baik dan sebagian dari apa yang Kami keluarkan dari bumi untuk kamu. Dan janganlah kamu memilih yang buruk-buruk lalu kamu menafkahkan daripadanya, padahal kamu sendiri tidak mau mengambilnya melainkan dengan memincingkan mata terhadapnya. Dan ketahuilah, bahwa Allah Maha Kaya lagi Maha Terpuji"”.

Perintah mengeluarkan zakat harta pada ayat tersebut, menurutnya mencakup semua harta kekayaan yang diusahakan dengan cara yang sah termasuk penghasilan usaha profesi. ${ }^{14}$ Surat At-Taubah ayat 103:

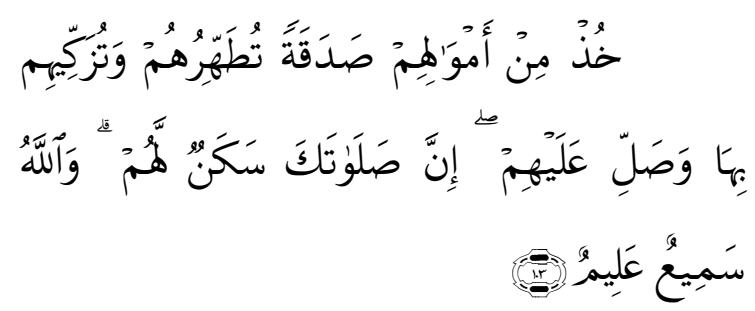

"Ambillah zakat dari sebagian harta mereka, dengan zakat itu kamu membersihkan dan mensucikan mereka dan mendoalah untuk mereka. Sesungguhnya doa kamu itu (menjadi) ketenteraman jiwa bagi mereka. Dan Allah Maha Mendengar lagi Maha Mengetahui”.
Kata amwal (harta) mencakup semua jenis kekayaan yang dimiliki dan dihasilkan dengan usaha yang halal. Argumen hadis yang digunakan adalah: "Sesungguhnya Allah telah mewajibkan umat Islam yang kaya kaya untuk mengeluarkan zakat dari harta mereka" (HR. Tabrani). Semua oarang kaya wajib mengeluarkan sebagian kekayaannya sebagai zakat termasuk pekerja profesi. $^{15}$

Penghasilan yang didapat dari pekerjaan seperti pendapatan pegawai dan golongan profesi yang didapat dari pekerjaan mereka maka besar zakatnya yang wajib dikeluarkan $2.5 \%$. sesuai dengan keumuman nash yang mewajibkan zakat uang sebanyak $2.5 \%$ dan sesuai dengan kaidah Islam yang menegaskan bahwa kesulitan atau kesukaran dapat meringankan besar kewajiban, serta mengikuti tindakan Ibnu Mas'ud dan Mu'awiyah yang telah memotong penghasilannya sebagai zakat, dari gaji para tentara dan para penerima gaji lainnya langsung di dalam kantor pembayaran gaji, juga sesuai dengan apa yang diterapkan oleh Khalifah Umar bin Abdul Aziz. ${ }^{16}$

Sehingga berdasarkan hal itu Yusuf Qaradhawi berpendapat bahwa zakat profesi wajib ditunaikan apa bila mencapai nisab uang, sedangkan penghasilan jika tidak mencapai nisab uang dalam setahun maka tidak wajib untuk ditunaikan zakatnya. ${ }^{17}$

\section{Teori An-Nama'Yusuf Qaradhawi}

Teori an-Nama yang dikemukaan oleh Yusuf Qaradhawi, menurut penulis sangat relevan untuk menyelesaikan masalah-masalah zakat yang seiringnya waktu memiliki perkembangan. Dan teori ini

\footnotetext{
${ }^{15}$ Dahlan dkk., Ensiklopedia Hukum, 1449.

${ }^{16}$ Dahlan dkk., 488.

${ }^{17}$ Qardawi, Hukum Zakat, 486.
} 
menurut penulis dapat diterapkan juga di Indonesia.

Wahbah Zuhaili sebagaimana dikutip oleh M Faiz Mufidi menegaskan bahwa berdasarkan istishlah atau maslahah mursalah, HKI termasuk harta yang dilindungi oleh syara'. Ditegaskan pula bahwa seorang pengarang berhak atas hak kepemilikan atas karyanya karena ia telah banyak mengeluarkan effort-nya dalam mempersiapkan ciptaannya. $^{18}$ Sehingga dengan adanya HKI tersebut akan berdampak pada perkembangan harta (dampak ekonomi) bagi seseorang yang memiliki HKI tersebut.

Secara umum Islam melindungi HKI, baik dari karya ilmiah, merek dagang atau logo dagang karena merupakan hak milik yang sah bagi penciptanya. Khususnya dimasa kini merupakan sebuah "Urf" atau kebiasaan yang diakui sebagai jenis dari suatu harat kekayaaan, dimana penciptanya (pemiliknya) berhak untuk memperjualbelikan dan merupakan komoditi. ${ }^{19}$ Islam memberikan perlindungan tujuannya untuk mejaga harta pada pemiliknya, karena HKI memiliki nilai ekonomi maka akan riskan untuk dapat dikuasai pihak lain. Sehingga dengan demikian Islam secra tidak langsung membenarkan bahwa HKI merupakan harta yang berkembang.

Al-Qaradhawi dalam teorinya tersebut, menjelaskan bahwa suatu harta yang diambil atau dikeluarkan zakatnya dapat berkembang atau dapat dikembangkan.

\footnotetext{
${ }^{18}$ M. Faiz Mufidi, "Aspek Fiqh Terhadap Hak Atas Kekayaan Intelektual (HAKI)," Jurnal Mimbar XXI (2005): 31., https://doi.org/10.29313/mimbar.v21i1.161.

${ }^{19}$ abd. Rochim Al-Audah, "Hak Cipta Dan Perlindungan Hak Kekayaan Intelektual Dalam Perspektif Hukum Islam Dan PerundangUndangan," Jurnal al-Maslahah IV (2016): 557.
}

Dalam bahasa modernnya, harta kekayaan tersebut dapat mendatangkan keuntungan. ${ }^{20}$

Al-Qaradhawi dalam kitabnya Fiqhuz Zakah mengutip pendapat Ibnu Humam, yang menyebutkan bahwa maksud daridisyariatkannya zakat yaitu pemberian beban atas kekayaan, yakni memberikan santunan orang-orang miskin, dengan besaran yang tidak akan membuat orang yang mengeluarkan zakat tersebut menjadi miskin pula, dengan cara memberikan sebagian kecil harta atau kekayaan yang banyak tadi. ${ }^{21}$

Menurutnya, bahwa mewajibkan zakat atas kekayaan yang tidak berkembangakan mengakibatkan kemiskinan jika terjadi bertahun-tahun khususnya bila diperlukan untuk kebutuhan sehari-hari. Dengan demikian dari sudut materi sungguh benar sabda Rasul yang artinya "Tidak akan berkurang kekayaan karena zakat”. Sehingga zakat tersebut hanya sebagian kecil yang wajib dikeluarkan dari suatu kekayaan yang banyak, berkembang, dan diinvestasikan yang berdasakan hukum alam (sunnatullah) tidak akan menguranginya, sesuai dengan hadis Rasul tersebut. ${ }^{22}$

Al-Qaradhawi menekankan bahwa kekayaan itu haruslah mempunyai sifat yang berkembang dan adanya potensi untuk dapat berkembang, bukan dikembangkan dengan sengaja, karena syariat Islam tidak mensyaratkan kemungkinan dapat dikembangkan dengan sengaja, sebab hal itu banyak menimbulkan pertentangan dan sulit diukur. Adapun yang dimaksudkan disini adalah bahwa memungkinan kekayaan itu menerima pengembangan dengan memperdagangkan atau membiakannya. Selain itu

\footnotetext{
${ }^{20}$ Yusuf Qaradhawi, Fiqhuz-Zakat (Beirut: Muassasatu Ar-Ris̄̄lah, 2002), 173.

${ }^{21}$ Qaradhawi, 173.

${ }^{22}$ Qaradhawi, 173.
} 
jika kekayaan itu tidak dapat berkembang sendiri, artinya merukan hasil investasi dan pendapatan, maka hanya wajib zakat apabila melalui usaha, semua itu dikembangkan, hasil usaha, dan keuntungan jerih payah. ${ }^{23}$

Sehingga dalam keadaan ini hukum syara' atau konsepsi yang dihasilkan merupakan upaya enginering, upaya membentuk masyarakat ke arah yang lebih sesuai dengan tututan kitab suci. Karena ini berkaitan dengan maslahat dalam perlindungan dan pemenuhan keperluan manusia. ${ }^{24}$

Perlindungan terhadap hak cipta dalam Islam memiliki syarat-syarat yang harus dipenuhi agar suatu karya cipta dapat diakui sebagai hak kepemilikan atas harta, yaitu: a). Tidak mengandung unsur-unsur haram didalamnya, b). Tidak menimbulkan kerusakan di masyarakat, c). Tidak bertentangan dengan syariat Islam secara umum). ${ }^{25}$

Salah satu bagian dari hukum perdata yaitu hukum kekayaan. Dalam hukum kekayaan ini mengatur mengenai hukum yang dapat dinilai dengan uang. Dalam konteks sistem Civil Law, bidang hukum ini mencakup hukum benda (zakenrecht) dan hukum perikatan (verbintenissenrecht). Dalam sistem Civil Law System, hukum kekayaan ini dikenal dengan atau setara law of property. Property sendiri mempunyai makna diderivasi dari bahasa latin, yakni proprius bermakna kepemilikan hak atau seseorang memiliki. Kemudian secara hukum, property bermakna

\footnotetext{
${ }^{23}$ Qaradhawi, 174.

${ }^{24} \mathrm{Al}$-Yasa' Abubakar, Metode Istislahiah (Pemanfaatan Ilmu Pengetahuan dalam Ushul Fiqh), Cet. I (Jakarta: Prenadamedia Group, 2016), 77.

${ }^{25}$ Agus Suryana, "Hak Cipta Perspektif Hukum Islam,” Jurnal al-Maslahah V (2015): 247.
}

sebagai hak eksklusif seseorang terhadap suatu benda. ${ }^{26}$

Satu pokok yang harus diketahui adalah kekhususan HKI terkait sifatnya yang merupakan benda tidak berwujud akan tetapi terkandung dalam benda yang berwujud. Kepemilikan atas benda yang berwujud tidak berarti juga memiliki benda yang tidak berwujud yang terkandung didalamnya. Sehingga, keberadaan HKI dalam suatu benda membatasi keleluasaan tindakan pemilik benda berwujud atas miliknya. Sebagai contoh, seseorang memiliki benda berwujud berupa buku, bukan berarti ia memiliki hak cipta sebagai benda tidak berwujud yang terkandung dalam buku tersebut. Artinya, pemilik buku tidak dapat menggandakan dan menjual buku tersebut tanpa ijin dari pemilik hak cipta atas buku tersebut. ${ }^{27}$

\section{HKI sebagai Harta dan Harta Tak Berwujud}

Hak atas kekayaan intelektual pada pokoknya merupakan hak untuk menikmati hasil dari kreatifitas intelektual seseorang secara ekonomi. Sehingga karenanya, objek yang diatur dalam hak atas kekayaan intelektual adalah karya-karya yang dihasilkan atau diwujudkan dari kemampuan intelektual manusia. $^{28}$

Hak atas kekayaan intelektual merupakan benda dalam hukum kekayaan. Istilah itu didasarkan pada kepemilikan

\footnotetext{
${ }^{26}$ Tim Penulis Pusat HKI FH UII, Wakaf Hak Kekayaan, 1-2.

${ }^{27}$ Indirani Wauran Wicaksono, "Hak Kekayaan Intelektual Sebagai Benda:Penelusuran Dasar Perlindungan Hki Di Indonesia," Jurnal Refeksi Hukum IX (2015): 139.

${ }^{28}$ Sudaryat, Sudjana, dan Rika Ratna Permana, Hak Kekayaan Intelektual,(Memahami Prinsip Dasar, Cakupan, dan Undang-Undang yang Berlaku), Cet. 1 (Bandung: Oase Media, 2010), 15.
} 
benda yang tidak berwujud. Meskipun benda tersebut tidak berwujud tetapi hukum mengakui bahwa hak yang timbul dari kekayaan intelektual sebagai bentuk hak atas kekayaan. Karena hak tersebut sebagai sebuah kekayaan, maka memiliki nilai uang tertentu. $^{29}$ Sehingga hak tersebut dapat menghasilkan harta atau menjadi sumber penghasilan bagi pemilik hak itu sendiri. Berdasarkan pengertian tersebut penulis berpendapat bahwa HKI adalah Hak berasal dari kegiatan olah pikir manusia yang memiliki manfaat ekonomi.

Secara garis besar, HKI dapat dibagi atau dikelompokkan dalam dua kelompok, yaitu kelompk Hak Cipta (copy right) dan kelompok Hak Kekayaan Industri (Industrial Property Right). Kelompok pertama terdiri dari hak cipta itu sendiri dan hak yang berkaitan dengan Hak Cipta (Nighbouring Right). Sedangkan kelompok kedua dapat diklasifikasikan menjadi patent (paten), utility model (model dan rancang bangun), dalam hukum Indonesia dikenal dengan istilah paten sederhana (simply patent), industrial design (desain industri), trademark (merek), Trade Names (nama niaga atau dagang), dan Indication of Source Applellation of Origin (Sumber tanda atau sebutan asal). ${ }^{30}$

Pandangan ahli misalnya di kalangan madzhab Syafi'i, al-Zarkasyi mengemukakan bahwa hak milik adalah sesuatu yang bermanfaat bagi pemiliknya, baik berupa pengambilan materi ataupun kemanfaatannya. Pendapat ini dikuatkan bahwa hak milik adalah suatu kemashlahatan yang

\footnotetext{
${ }^{29}$ Tim Penulis Pusat HKI FH UII, Wakaf Hak Kekayaan, 6.

${ }^{30}$ Eva Mir'atun Niswah, "Problematika Yuridis Wakaf Hak Kekayaan Intelektual Di Indonesia," Volksgeist: Jurnal Ilmu Hukum Dan Konstitusi 1, no. 2 (31 Desember 2018): 136, https://doi.org/10.24090/volksgeist.v1i2.1907.
}

mempunyai nilai ekonomi yang dilindungi oleh Undang-Undang, selain terpenuhinya unsur nilai di dalamnya. Dengan demikian, hak milik tidak selalu berwujud materi, tetapi juga mencakup immateri yang dapat diambil manfaat dan memiliki nilai ekonomi bagi si pemiliknya. Sama halnya dengan hak cipta, maka mengacu pada sesuatu yang dapat diambil manfaat oleh pemiliknya. Hak cipta memiliki nilai ekonomi yang tinggi. Wajar bila banyak terjadi kasus pembajakan terhadap hak cipta. Suatu ciptaan (al-ibtikar) adalah buah karya yang muncul dari kemampuan seorang ilmuan dalam menggali inovasi dan kreasi yang belum diketemukan orang lain. Karenanya, negara sebagai pemegang otoritas dalam mengelola keteraturan maka negara wajib memberikan perlindungan atas suatu temuan. ${ }^{31}$

Sedangkan kalangan madzhab Maliki, Imam Syatibi dalam kitab alMuwafaqat menyatakan bahwa yang dimaksud harta ialah apa pun yang berada di bawah penguasaannya yang menjadikannya terhalang bagi orang lain untuk menguasainya. Selain itu, ia menyatakan bahwa ketentuan hak milik terhadap sesuatu yang kemudian dapat dikategorisasikan ke dalam harta ialah ketika sesuatu tersebut dilegitimasi atau diakui oleh al-' $u r f .{ }^{32}$ Berdasarkan konsep tersebut, dapat diambil sebuah garis besar bahwa harta tersebut tetap

\footnotetext{
${ }^{31}$ Fathi al-Daraini, Haq Al-Ibtikar fi Al-Fiqh Al-Muqarin (Beirut: Matba'ah Muassasah alRisalah, ttp), 23.

${ }^{32} \mathrm{Abu}$ Ishaq asy-Syathibi, Al-Muwafawat fi Ușul Al-Syarī'ah, Juz II (Beirut: Dār Ma'rifah, ttp), hlm. 17.Para ulama menggunakan istilah 'urf untuk menjelaskan adat kebiasaan yang berlaku di masyarakat dan dibenarkan agama. Istilah lainnya disebut 'Ādah. Term 'ādah lebih sering digunakan daripada 'urf. 'Addah lebih general dibanding 'urf. BacaAyman Shaban, Custom in Islamic Law and Legal Theory; The Development of The Concept of 'Urf and 'Ādah in The Islamic Legal Tradition (New York: Palgrave Macmillan, 2010), 50.
} 


\section{Volksgeist}

Vol. 3 No. 1 Juni 2020

DOI 10.24090/volksgeist.v3i1.3503

menjadi miliki yang berhak, kecuali berpindah tangan karena adanya sebab yang dilegalkan oleh syara' seperti jual beli, wakaf, hibah, atau wasiat. Poin selanjutnya, segala sesuatu yang diakui oleh 'ādah atau 'urf baik barang tersebut berupa material ataupun immaterial yang dapat digolongkan ke dalam harta. Dengan demikian, dalam pandangan al-Syatibi, sesuatu yang bersifat immaterial dapat dikategorisasikan sebagai hak milik, sepanjang hal itu sesuai dengan akad dan tata nilai yang keberadaannya berlaku di masyarakat. Atas dasar itu, bahwa hak cipta atau HAKI merupakan hak milik, karena keberadannya telah diakui oeh masyarakat sebagai sesuatu yang berharga. ${ }^{33}$

Pada dasarnya prinsip utama pada HKI adalah bahwa hasil kreasi dan perkerjaan dengan menggunakaan kemampuan intelektual seseorang tersebut, sehingga seseorang yang menghasilkannya memiliki kepemilikan berupa hak alamiah. Sehingga dapat dikataan dengan dasar prinsip ini terdapat sifat eksklusif bagi pencipta. Sebagai cara untuk menyeimbangkan kepentingan antara peranan pribadi individu dengan kepentingan masyarakat, maka HKI berdasarkan pada prinsip. ${ }^{34}$

a. Prinsip Keadalian (the principle of natural justice)

Atas dasar prinsip tersebut, maka pencipta sebuah karya, atau orang lain yang bekerja untuk mengahsilkan karya dari kemampuan intelektualnya

\section{b. Prinsip Ekonomi (the economic argument)}

Berdasarkan prinsip ini suatu kepe

${ }^{33}$ Abd. Salam Arief, "Konsep Al-Mal dalam Perspektif Hukum Islam (Studi terhadap Ijtihad Fuqaha)," Jurnal al-Mawarid Edisi IX (2003): 50.

${ }^{34}$ Muhamad Djumhana dan R Djubaedillah, Hak Milik Interlektual: Sejarah, Teori dan Prakteknya di Indonesia (Bandung: Citra Aditya Bakti, 1997), 25-26. milikan adalah merupakan hal yang wajar, karena sifat ekonomi manusia yang menjadikan hal tersebut suatu keharusan untuk menunjang kehidupannya dalam masyarakat.

c. Prinsip Kebudayaan (the culture argument)

Pada Hakikatnya karya manusia bertujuan untuk meningkatkan hidup. Selanjutnya karya itu akan timbul suatu gerak hidup yang harus menghasilkan lebih banyak karya lagi. Dengan demikian pertumbuhan dan perkembangan karya manusia sangat besar artinya bagi peningkatan taraf kehidupan, peradaban, dan martabat manusia.

d. Prinsip Sosial (the sosial argument)

Pemberian hak oleh hukum tidak boleh diberikan semata-mata untuk memenuhi kepentingan perseorangan, akan tetapi harus memenuhi kepentingan seluruh masyarakat.Hal ini sejalan dengan salah satu prinsip maqasid syariah kontemporer dalam hal menjaga harta. ${ }^{35}$

Hak Atas Kekayaan Intelektual pada dasarnya merupakan bagian dari benda, yakni benda tidak berwujud (bena immateriil). Benda dalam kerangka hukum perdata dikategorikan menjadi dua kelompok, yakni: ${ }^{36}$

a. Benda berwujud (materiil)

b. Benda tidak berwujud (immateriil). 


\section{Pengembangan Jenis Zakat Hak Atas Kekayaan Intelektual}

Yusuf al-Qaradhawi mengatakan bahwa harta kekayaan yang diperoleh dari sumber mata pencaharian yang legal (sah) yang telah mencapai nisabnya wajib dikeluarkan zakat. Termasuk didalamnya kekayaan yang dihasilkan dari penghasilan profesi. Hasil pemikirannya didasarkan pada Al-Qur'an, sunnah dan logika. Akan tetapi, sekalipun bukan dalam bentuk taklid, alQaradhawi banyak juga menukil dan kadang-kadang menguatkan pendapat ulama fikih klasik. Ini dapat terlihat jelas dalam tulisannya Fiqh az-Zakah (Fikih Zakat). ${ }^{37}$

Mengenai zakat profesi para ulama menyebutkan bahwa nash-nash yang bersifat umum untuk dijadikan hujjah tentang zakat profesi diantaranya adalah firman Allah dalam surat at-Taubah ayat 103, al-Baqarah ayat 267, dan adz-Dzariyat ayat 19 yang berbunyi:

$$
\text { و في أموالهم حقّ للسّائل و المحروم (الذاريات: } 9
$$

"Dan pada harta-harta mereka ada hak untuk orang miskin yang meminta, dan orang miskin yang tidak mendapat bagian".

Al-Qurthubi dalam Tafsir al-Jami’ li Ahkam Al-Qur'an menyatakan bahwa yang dimaksud dengan kata-kata haqqun ma'lum (hak yang pasti) pada surat adz-Dzariyat ayat 19 adalah zakat yang diwajibkan, bagi semua harta yang dimiliki dan semua penghasilan yang didapat dan dicari jika telah memenuhi syarat nisab zakat maka wajib zakatnya untuk dikeluarkan. ${ }^{38}$

\footnotetext{
${ }^{37}$ Dahlan dkk., Ensiklopedia Hukum, 1449.

${ }^{38}$ Didin Hafidhuddin, Zakat dalam Perekonomian Modern, Cet. 2 (Jakarta: Gema Isani, 2002), 94-95.
}

Yusuf Al-Qaradhawi dalam mengambil hukum zakat profesi, ayat yang digunakan sebagai landasan adalah surat AlBaqarah ayat 267.

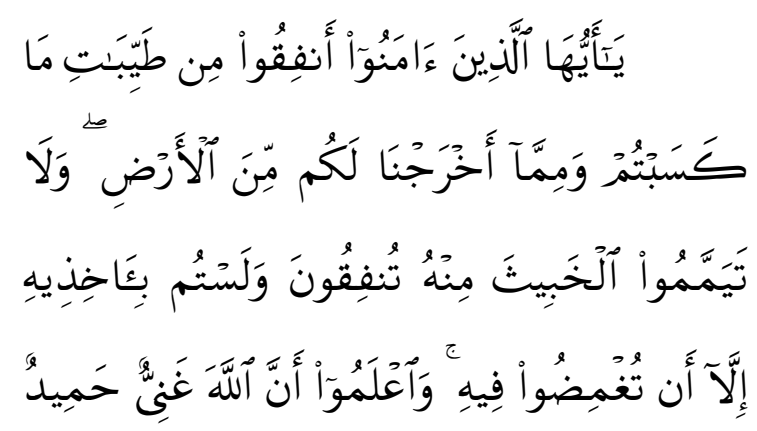

Hai orang-orang yang beriman, nafkahkanlah (di jalan allah) sebagian dari hasil usahamu yang baik-baik dan sebagian dari apa yang Kami keluarkan dari bumi untuk kamu. Dan janganlah kamu memilih yang buruk-buruk lalu kamu menafkahkan daripadanya, padahal kamu sendiri tidak mau mengambilnya melainkan dengan memincingkan mata terhadapnya. Dan ketahuilah, bahwa Allah Maha Kaya lagi Maha Terpuji”

Perintah mengeluarkan zakat harta pada ayat tersebut, menurutnya mencakup semua harta kekayaan yang diusahakan dengan cara yang sah termasuk penghasilan usaha profesi. ${ }^{39}$ Dalam kaitannya dengan hal ini, Hak atas kekayaan intelektual merupakan bagian dari suatu mata pencaharian yang sah. Penetapan Hak atas kekayaan intelektual banyak mendorong seseorang untuk berkarya dengan kemampuannya untuk mengeluarkan ide-ide atau perubahan pada perkembangan zaman seperti sekarang ini. Maka hasil intelektual yang telah dicetuskan akan disisikan

\footnotetext{
${ }^{39}$ Dahlan dkk., Ensiklopedia Hukum, 1449.
} 


\section{Volksgeist}

Vol. 3 No. 1 Juni 2020

DOI 10.24090/volksgeist.v3i1.3503

hartanya dengan melalui yang namanya zakat. Sehingga dalam penyelesaiannya dalam masalah zakat, lebih tepat di qiyaskan pada zakat profesi yang didasarkan pada ijtihad Yusuf al-Qaradhawi. Dimana profesi dan hak atas kekayaan intelektual merupakan sebuah mata pencaharian atau sumber rezeki untuk tiap masyarakat.

\section{Perhitungan Zakat Hak Atas Kekayaan Intelektual}

Berkaitan permasalahan nisab, Yusuf Qaradhawi berpendapat bahwa penghasilan yang mencapai nisab wajib diambil zakatnya. Hal ini di dasarkan pada pendapat Zuhri dan Auza'i, baik dengan mengeluarkan zakatnya saat diterimanya harta tersebut ataupun dengan mengundurkan pengeluaran zakatnya sampai batas setahun bila ia tidak khawatir untuk membelanjakannya. Akan tetapi bila ia khawatir untuk membelanjakannya maka ia harus mengeluarkan zakatnya segera. ${ }^{40}$

Penghasilan yang didapat dari modal saja atau modal kerja seperti penghasilan pabrik, gedung, percetakan, hotel, mobil, kapal terbang dan sejenisnya, besar zakatnya adalah sepersepuluh (10\%) dari pendapatan bersih setelah biaya kebutuhan-kebutuhan pokok dan lain-lainnya dikeluarkan. Hal ini didasarkan pada penghasilan dari pertanian yang diairi tanpa ongkos tambahan. ${ }^{41}$ Jika ada tambahan ongkos maka zakatnya $5 \%$.

Pendapatan yang diperoleh dari pekerjaan seperti pendapatan pegawai dan golongan profesi yang mereka peroleh dari pekerjaan mereka maka besar zakat yang dikeluarkan adalah seperempat puluh (2.5\%). Ini sesuai dengan keumuman nash yang mewajibkan zakat uang sebanyak

\footnotetext{
${ }^{40}$ Qardawi, Hukum Zakat, 485.

${ }^{41}$ Qardawi, 488.
}

seperempat puluh, baik harta penghasilan maupun harta yang bermasa tempo, dan sesuai dengan kaidah Islam yang menegaskan bahwa kesukaran dapat meringankan besar kewajiban serta mengikuti tindakan Ibnu Mas'ud dan Mu'awiyah yang telah memotong besaran tertentu berupa zakat dari gaji para tentara besar langsung dari kantor pembayaran gaji, juga sesuai dengan yang telah ditetapkan oleh khalifah Umar bin Abdul Aziz. ${ }^{42}$

Untuk menyelesaikan masalah zakat kekayaan intelektual ini, penulis menggunakan metode qiyas atau analogi dalam mengategorikan hak atas kekayaan intelektual, yang disandarkan pada hasil ijtihad hadits nabi yang mewajibkan zakat perak sebagai mata uang (riqqoh).

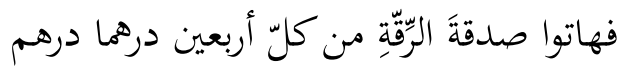

"Datangkanlah (bayarlah) zakat riqqah (perak sebagai mata uang) yaitu setiap dari 40 dirham (zakatnya) 1 dirham" (HR. Abu Dawud I/494 no. 1574). ${ }^{43}$

Dimana zakat uang atau nuqud yakni sebesar 2,5\%, sejumlah zakat yang dikeluarkan pada emas setelah mencukupi nisab dan haulnya. Dan setelah dikeluarkan kebutuhan-kebutuhan pokoknya. Sehingga pada hal ini antara HKI dan Uang memilki kesamaan 'illat hukum, yakni sebagai harta kekayaan yang dapat berkembang. Sehingga hukumnya untuk mengeluarkan zakat tersebut wajib

Pada sisi yang lain Yusuf Qaradhawi dalam menetapkan kadar zakat profesi juga menggunakan qiyas, Qiyas ini menempatkan

\footnotetext{
${ }^{42}$ Qardawi, 488.

${ }^{43}$ Imam Abu Dawud, Sunan Abu Dawud (Beirut: Dōrul Kutub Al-Alamiyah, ttp), 494.
} 
zakat profesi pada posisi furu', sehingga haruslah disandarkan pada jenis zakat lain (asal) yang ketentuannya secara qat'i telah diatur oleh syari'at baik dari segi kadar, nisab, dan haulnya. Misalkan jika zakat profesi diqiyaskan pada nuqud (emas, perak, dan uang) maka kadarnya adalah 2,5\% nisabnya senilai 85 gram emas dan waktu pengeluarannya satu tahun sekali yang telah dikurangi untuk kebutuhan pokok dan beban hutangnya. $^{44}$

Sehingga dalam hal ini, zakat hak atas kekayaan intelektual wajib ditunaikan layaknya zakat profesi, karena perintah zakat pada dasarnya wajib, maka hal ini berlaku pula terhadap zakat hak atas kekayaan intelektual. Selain itu pula, hak atas kekayaan baik dari hukum yang berlaku indonesia maupun ulama fikih, merupakan bagian dari harta kekayaan, yakni dalam kategori harta tak berwujud, serta memiliki nilai ekonomi atau qimah.

\section{Penutup}

Berdasarkan uraian dan analisa yang telah dipaparkan di atas maka peneliti akhirnya dapat menyimpulkan hasil dari penelitian ini, sebagai berikut;

Pertama, respon fikih terhadap fenomena zakat HKI diwujudkan dengan mengakomodir dua teori, yakni teori zakat an-nama' dan teori kebendaan. Karena hak atas kekayaan intelektual merupakan harta (benda tak berwujud) yang memiliki nilai ekonomi, yang dihasilkan dari kreatifitas intelektual manusia dan diwujudkan dengan karya tertentu yang memiliki daya guna. Sehingga hak atas kekayaan intelektual termasuk harta yang berkembang. Oleh karena itu, hak atas kekayaan intelektual

${ }^{44}$ Ma'shum Zein, Menguasai Ilmu Ushul Fiqh (Yogyakarta: Pustaka Pesantren, 2013), 111. wajib dikeluarkan zakatnya. Dan Hak atas kekayaan intelektual merupakan bagian zakat Profesi, karena HKI memiliki nilai ekonomi, yang dihasilkan dari kreatifitas Intelektual yang diwujudkan dengan karyakaryanya.

Kedua, pelaksanaan zakat hak atas kekayaan intelektual diberlakukan perhitungan dalam pengeluarannya yakni sebesar $2.5 \%$ dari penghasilan yang didapat setelah dikeluarkannya kewajiban pokok serta telah tercapai haul dan nisabnya. Nisab untuk mengelurakan zakat hak atas kekayaan intelektual itu sendiri didasarkan pada zakat nuqud yakni senilai dengan nisab uang atau sejumlah 85 gram emas.

\section{Daftar Pustaka}

Abubakar, Al-Yasa'. Metode Istislahiah (Pemanfaatan Ilmu Pengetahuan dalam Ushul Fiqh). Cet. I. Jakarta: Prenadamedia Group, 2016.

Al-Audah, Abd. Rochim. "Hak Cipta dan Perlindungan Hak Kekayaan Intelektual dalam Perspektif Hukum Islam dan PerundangUndangan." Jurnal al-Maslahah IV (2016): 557-80.

Arief, Abd. Salam. "Konsep Al-Mal dalam Perspektif Hukum Islam (Studi terhadap Ijtihad Fuqaha)." Jurnal al-Mawarid Edisi IX (2003): 4857.

Asnaini. Zakat Produktif dalam Perspektif Hukum Islam. Cet. 1. Yogyakarta: Pustaka Pelajar, 2008.

Bakry, Hasbullah. Pedoman Islam di Indonesia. Cet. 5. Jakarta: UI Press, 1988.

Dahlan, Abdul Aziz, Ritonga, Ahmad Thaib Raya, dan Yaswirman. Ensiklopedia Hukum Islam. Disunting oleh Abdul Aziz Dahlan. Jakarta: PT. Ikhtiar Baru Van Hoeve, 1997. 
Daraini, Fathi al-. Haq Al-Ibtikar fi AlFiqh Al-Muqarin. Beirut: Matba'ah Muassasah al-Risalah, ttp.

Dawud, Imam Abu. Sunan Abu Dawud. Beirut: Dōrul Kutub Al-Alamiyah, ttp.

Departemen Agama RI. Al-Qur'an dan Terjemahannya. Bandung: PT. Sygma Examedia Arkanleema, 2009.

Djumhana, Muhamad, dan R Djubaedillah. Hak Milik Interlektual: Sejarah, Teori dan Prakteknya di Indonesia. Bandung: Citra Aditya Bakti, 1997.

Hafidhuddin, Didin. Zakat dalam Perekonomian Modern. Cet. 2. Jakarta: Gema Isani, 2002.

Huda, Nurul, Novarini, Yosi Mardono, dan Citra Permata Sari. Zakat Perspektif Mikro-Makro: Pendekatan Riset. Cet. 1. Jakarta: Prenadamedia Group, 2015.

Juliansyahzen, Muhammad Iqbal. "Good Governance Perspektif Maqaasid Asy-Syaari'ah Kontemporer." AKADEMIKA: Jurnal Pemikiran Islam 23, no. 1 (18 Agustus 2018): 57-86.

https://doi.org/10.32332/akademika .v23i1.1195.

Mth, Asmuni. "Hak Milik Intelektual dalam Perspektif Fiqh Islam." Jurnal al-Mawarid Edisi IX (2003): 28-47.

Mufidi, M. Faiz. "Aspek Fiqh terhadap Hak Atas Kekayaan Intelektual (HAKI)." Jurnal Mimbar XXI (2005): 23-35. https://doi.org/10.29313/mimbar.v2 1i1.161.

Niswah, Eva Mir'atun. "Problematika Yuridis Wakaf Hak Kekayaan Intelektual Di Indonesia." Volksgeist: Jurnal Ilmu Hukum Dan Konstitusi 1, no. 2 (31 Desember 2018): 123-38. https://doi.org/10.24090/volksgeist. v1i2.1907.
Pemerintah Republik Indonesia. UndangUndang Nomor 23 Tahun 2013 tentang Pengelolaan Zakat, 2013.

Purba, Afrillyanna, Gazalba Saleh, dan Andriana Krisnawati. Trips-Wto \& Hukum HKInIndonesia: Kajian Perlindungan Hak Cipta Seni Batik Tradisional Indonesia. Cet. 1. Jakarta: Rineka Cipta, 2005.

Qaradhawi, Yusuf. Fiqhuz-Zakat. Beirut: Muassasatu Ar-Risōlah, 2002.

Qardawi, Yusuf. Hukum Zakat. Diterjemahkan oleh Salman Harun, Didin Hafidhuddin, dan Hasanuddin. Cet. 10. Jakarta: Pustaka Litera AntarNusantara, 2007.

Shaban, Ayman. Custom in Islamic Law and Legal Theory; The Development of The Concept of 'Urf and 'Ādah in The Islamic Legal Tradition. New York: Palgrave Macmillan, 2010.

Shalehuddin, Wawan Shofwan. Risalah Zakat: Infak dan Shadaqah. Cet. 1. Bandung: Tafakur, 2011.

Shiddieqy, Teungku Muhammad Hasbi ash-. Pedoman Zakat. Cet. 2. Semarang: Pustaka Rizki Putra, 1999.

Sudaryat, Sudjana, dan Rika Ratna Permana. Hak Kekayaan Intelektual,(Memahami Prinsip Dasar, Cakupan, dan UndangUndang yang Berlaku). Cet. 1. Bandung: Oase Media, 2010.

Suryana, Agus. "Hak Cipta Perspektif Hukum Islam." Jurnal al-Maslahah V (2015): 247-73.

Syathibi, Abu Ishaq asy-. Al-Muwafawat fì Ușul Al-Syarīah. Juz II. Beirut: Dār Ma'rifah, ttp.

Tim Penulis Pusat HKI FH UII. Wakaf Hak Kekayaan Intelektual. Yogyakarta: Fakultas Hukum UII, 2016.

Wicaksono, Indirani Wauran. "Hak Kekayaan Intelektual Sebagai Benda: Penelusuran Dasar 


\section{Volksgeist}

Vol. 2 No. 2 Desember 2019 DOI 10.24090/volksgeist.v3i1.3503

Perlindungan Hki di Indonesia." Jurnal Refeksi Hukum IX (2015).

Zadeh, M. Husein Falah. Belajar Fiqih untuk Tingkat Pemula. Jakarta: Raja Grafindo Persada, 2008.
Zein, Ma'shum. Menguasai Ilmu Ushul Fiqh. Yogyakarta: Pustaka Pesantren, 2013. 